\title{
Perancangan Ulang Alat Pemotong Kerupuk Dengan Menggunakan Metode Triz (Teorija Rezhenija Izobretatelskih Zadach)
}

\author{
Christoforus Angelus Wijaya, Martinus Edy Sianto*, Hadi Santosa* \\ Jurusan Teknik Industri, Faku ltas Teknik, Universitas Katolik Widya Mandala Surabaya, Jalan Kalijudan \\ 37 Surabaya \\ *e-mail : martinus.sianto@gmail.com
}

\begin{abstract}
ABSTRAK
Kerupuk merupakan makanan ringan khas asli Indonesia yang menjadi hidangan pendamping pada beberapa masakan-masakan Indonesia. Proses pembuatan kerupuk meliputi pencampuran bahan baku, pembuatan adonan, pencetakan, pengukus an, pendinginan, pengiris an, peng eringan, dan pemasakan. Dari beberapa proses pembuatan kerupuk tersebut, ada satu proses yang cukup penting diperhatikan yaitu proses pemotongan kerupuk. Hasil pengamatan yang dilakukan di UMKM Srikandi Sumber Laut yang berfokus pada olahan hasil laut menunjukkan bahwa pemillik UM KM masih menggunakan alat pemotong kerupuk secara manual. Untuk memenuhi permintaan konsumen, pemilik menginginkan alat pemotong kerupuk agar dapat menghasilkan kuantitas yang banyak dan kualitas potongan kerupuk yang baik (ukuran dan dimensi kerupuk yang seragam). Dalam penelitian ini digunakan metode TRIZ dalam merancangan ulang alat pemotong kerupuk. Hasil dari penelitian ini yaitu bentuk pisau yang dibuat melengkung, pemotongan 3 adonan dalam 1 rotasi. Penggunaan baja JIS SKD 11 sebagai bahan dasar pisau utama agar dapat me motong lontongan kerupuk dengan baik.
\end{abstract}

Keywords: Crackers; Crackers Cutter; TRIZ Theory; Tool Design.

\section{Pendahuluan}

Indonesia merupakan negara kepulauan yang sebagian besar luas wilayahnya merupakan perairan. Ikan merupakan salah satu hasil perikanan yang banyak dihasilkan di Indonesia dan merupakan sumber protein hewani yang banyak dikonsumsi masyarakat. Ikan mudah didapat dengan harga yang relatif murah sehingga dapat dijangkau oleh semua lapisan masyarakat. Salah satu makanan ringan hasil olahan ikan yaitu kerupuk. Kerupuk merupakan makanan ringan khas asli Indonesia yang menjadi hidangan pendamping pada beberapa masakan-masakan Indonesia.

Proses pembuatan kerupuk meliputi pencampuran bahan baku, pe mbuatan adonan, pencetakan, pengukusan, pendinginan, pengirisan, pengeringan, dan pemasakan. Dari beberapa proses pembuatan kerupuk tersebut, ada satu proses yang cukup penting diperhatikan yaitu proses pengirisan kerupuk. Hasil pengamatan yang dilaku kan di UMKM Srikandi Sumber Laut yang berfokus pada olahan hasil laut menunjukkan bahwa pemillik UMKM masih menggunakan alat pemotong kerupuk secara manual.

Perkembangan teknologi di jaman sekarang semakin canggih dan banyak membantu manusia dalam memudahkan menyelesaian pekerjaannya dalam waktu yang relatif cepat dan efisien. Alat pemotong lontongan kerupuk adalah suatu alat tepat guna yang dapat mempercepat dan mempermudah proses pemotongan. Perancangan ulang alat pemotong kerupuk ini mengacu pada penelitian yang dikembangkan oleh Aryotantra, Julian (2018) yang berjudul Perancangan Pisau Pemotong Kerupuk Dengan Menggunakan Metode TRIZ dan Citro, Julius Kurniawan (2018) yang berjudul Perancangan launcher Pemotong Kerupuk menggunakan Metode TRIZ.

Setelah alat diamati dan diteliti, terdapat salah satu part yang perlu dirancang ulang yaitu part pisau pemotong. Pada saat proses pemotongan kondisi pisau hanya diletakkan di alat pemotong tanpa diberi penyangga apapun. Hal tersebut mengakibatkan posisi pisau bergoyang atau tidak stabil sehingga hasil potongnya bervariasi. Selain itu, pengguna masih belum dapat mengatur ketebalan hasil pemotongan kerupuk. Oleh karena itu dibutuhkan rancangan ulang agar alat pemotong dapat bekerja secara optimal.

II. Landasan Teori

II.1. Pengertian Teorija Rezhenija
Izobretatelskih Zadach(TRIZ)
Model pemecahan masalah Teorija Rezhenija Izobretatelskih Zadach (TRIZ) adalah teori yang ditemukan oleh Genrich Saulovich Altshuller dari Uni Soviet pada tahun 1946 yang 
melakukan penelitian 400.000 patent dari berbagai macam bidang teknik. TRIZ seringkali diterjemahkan ke dalam bahasa inggris sebagai Theory of Inventive Problem Solving (TIPS) yang memiliki arti teori inovatif pemecah masalah. Altshuller mendapatkan cara untuk menyelesaikan permasalahan inventif yang kompleks dengan melakukan identifikasi dan mengkategorikan setiap solusi yang ada. Pengkategorian setiap solusi tersebut telah dirumuskan oleh Altshuller di dalam 40 prinsip TRIZ. Terdapat tiga buah prinsip dasar yang diterapkan untuk mendapatkan solusi yang terbaik :

1. Solusi harus dapat menyelesaikan kontradiksi yang menjadi penyebab masalah.

2. Mencari idealitas dari suatu sistem. Idealitas dari sistem yang merupakan ukuran dari seberapa dekat dengan hasil yang sempurna.

3. Penggunaan sumber daya alam yang sering kali tidak terlihat, menganggur, atau tidak pernah dipakai sebelumnya.

Terdapat beberapa langkah dalam penggunaan Metode TRIZ yang harus dilakukan yaitu: Langkah 1 : Menggambarkan masalah.

Langkah 2 : Menyesuaikan dan me mbandingkan masalah umum dengan TRIZ problems.

Langkah 3 : mencari solusi TRIZ.

Langkah 4 : Mengembangkan solusi ideal untuk masalah.

\section{Metodologi Penelitian}

Langkah-langkah yang dilakukan dalam mencapai tujuan penelitian dimulai dari studi pustaka. Pada tahap ini dilakukan pengumpulan data dengan cara penelaahan terhadap buku, literatur, dan jurnal yang berhubungan dengan metode TRIZ agar dapat digunakan dalam merancang ulang alat pemotong adonan kerupuk. Lalu tahapan selanjutnya adalah pengamatan lapangan dimana pada tahap ini dilaku kan pengumpulan data yang diambil dari skripsi yang berjudul Perancangan Pisau Pemotong Kerupuk oleh Aryotantra, Julian (2018) dan Perancangan Launcher Pemotong Kerupuk oleh Citro, Julius Kurniawan (2018) dengan mengamati ukuran, bentuk, dan bagian-bagian (part) dari alat pemotong kerupuk sebelumnya seperti launcher, pisau pemotong, as, mur dan baut.

Data yang dikumpulkan akan digunakan dalam proses perancangan ulang alat pemotong kerupuk. Tahapan selanjutnya yaitu menetapkan kriteria, pada tahap ini dilakukan identifikasi kriteria-kriteria yang diinginkan serta kendala yang dihadapi. Langkah selanjutnya yaitu merinci masalah berdasarkan kriteria, pada tahapan ini dilakukan perincian masalah yang didasari pada kendala- kendala yang didapatkan dari desain alat pemotong kerupuk. Setelah masalah dirinci, langkah selanjutnya adalah identifikasi masalah berdasarkan Altshuller's 39 Parameter. Pada tahap ini dilakukan pengelompokkan data masalah antara pernyataan yang bertentangan dan pernyataan yang tidak bertentangan. Langkah selanjutnya yaitu merinci strategi berdasarkan matriks kontradiksi dimana langkah tersebut menjelaskan tentang perumusan beberapa strategi alternatif dengan cara mengu mpulkan setiap data parameter dan diolah menggunakan matriks kontradiksi.

Setelah itu, langkah berikutnya adalah perancangan ulang alat pemotong kerupuk, Berdasarkan strategi penyelesaian masalah yang telah ditemukan dilakukan perancangan ulang pada alat pemotong kerupuk. Setelah alat tersebut dirancang ulang, langkah selanjutnya yaitu pembuatan prototype dimana langkah ini menjelaskan tentang pembuatan prototype alat pemotong kerupuk berdasarkan desain, konsep, dan bahan baku yang telah ditetapkan sebelumnya. Gambar desain tersebut dibawa ke bengkel untuk dibuat oleh tukang. Setelah alat tersebut jadi, langkah selanjutnya yaitu proses pengujian alat pemotong kerupuk, Pada tahap ini, dilakukan pengujian pada alat yang telah dibuat. Pengujian dilakukan dengan cara memotong lontongan dengan pisau yang telah dirancang.

Langkah selanjutnya yaitu analisa alat yang telah diuji dengan tujuan untuk mengetahui kesesuaian hasil terhadap tujuan yaitu peningkatan produktivitas, kerapian pemotongan dan pengaturan ketebalan dimensi pemotongan. Selain itu analisa dilakukan untuk mengetahui kekurangan dan kelebihan alat serta rincian anggaran yang diperlukan dalam pembuatan alat. Tahap terakhir yaitu pengambilan kesimpulan dan saran agar dapat bermanfaat bagi peneliti selanjunya.

\section{Hasil dan Pembahasan \\ IV.1. Menetapkan Kriteria}

Berdasarkan hasil wawancara yang telah dilakukan mengenai proses pembuatan kerupuk didapatkan kriteria yang ingin dicapai oleh pekerja dalam perancangan ulang alat pemotong kerupuk adalah sebagai berikut:

1. Alat yang dapat memotong lontongan kerupuk dengan kuat dan cepat.

2. Alat pemotong kerupuk dapat mudah dioperasikan.

Pisau stabil/ tidak goyang pada saat proses pemotongan.

IV.2. Merinci Masalah Berdasarkan Kriteria

Berdasarkan dari hasil observasi dan wawancara yang telah dilakukan di Home Industry kerupuk, Kecamatan Bulak, Surabaya 
terdapat beberapa masalah yang dialami pada perancangan alat pemotong kerupuk sebelumnya sebagai berikut :

1. Bagaimana cara agar alat dapat memotong lontongan kerupuk dengan kuat dan cepat?

2. Bagaimana cara merancang alat pemotong kerupuk agar mudah dioperasikan?

3. Bagaimana cara merubah desain pisau agar stabil/ tidak goyang pada saat proses pemotongan?

IV.3 Mengidentifikasi Masalah dengan Altshuller's 39 Parameter

Identifikasi Parameter yang sesuai dapat dilihat pada Tabel 1.

Tabel 1. Identifikasi Altshuller's 39 Parameter

\begin{tabular}{|c|l|c|c|}
\hline No & \multicolumn{1}{|c|}{ Keterangan } & Parameter & Kode \\
\hline 1 & $\begin{array}{l}\text { Cara agar alat } \\
\text { dapat memotong } \\
\text { lontongan kerupuk } \\
\text { dengan kuat dan } \\
\text { cepat }\end{array}$ & Strength (\#14) & 14 \\
\hline 2 & $\begin{array}{l}\text { Cara merancang } \\
\text { alat agar mudah } \\
\text { dioperasikan }\end{array}$ & $\begin{array}{c}\text { Ease of } \\
\text { operation (\#33) }\end{array}$ & 33 \\
\hline 3 & $\begin{array}{l}\text { Cara merubah } \\
\text { desain pisau agar } \\
\text { stabil/ tidak } \\
\text { goyang pada saat } \\
\text { proses pemotongan }\end{array}$ & Shape (\#12) & 12 \\
\hline
\end{tabular}

\section{Analisa Data}

\section{V.1. Perancangan Ulang Alat Pemotong Kerupuk}

Dengan melakukan proses kontradiksi diperoleh solusi untuk menyelesaikan masalah pada Tabel 1. Proses kontradiksi dapat dilihat pada Tabel 2, Tabel 3, dan Tabel 4. Melalui solusi-solusi yang telah didapatkan dengan metode TRIZ (Teorija Rezhenija Izobretatelskih Zadach) maka dilakukan perancangan ulang desain alat dengan bentuk, ukuran, dan cara kerja alat seperti yang terlihat pada gambar 1 dan 2.

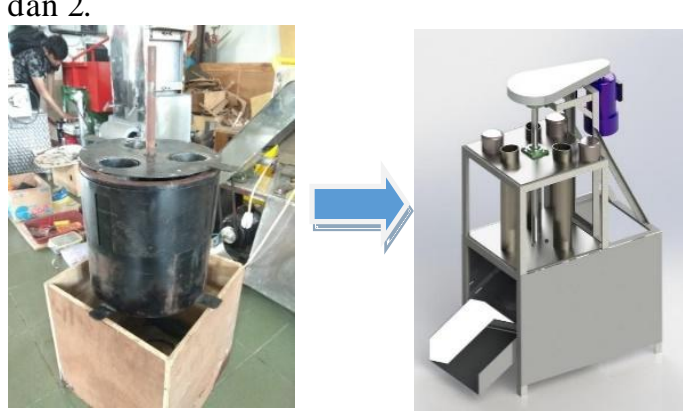

Gambar 1. Rancangan Awal dan rancangan usulan

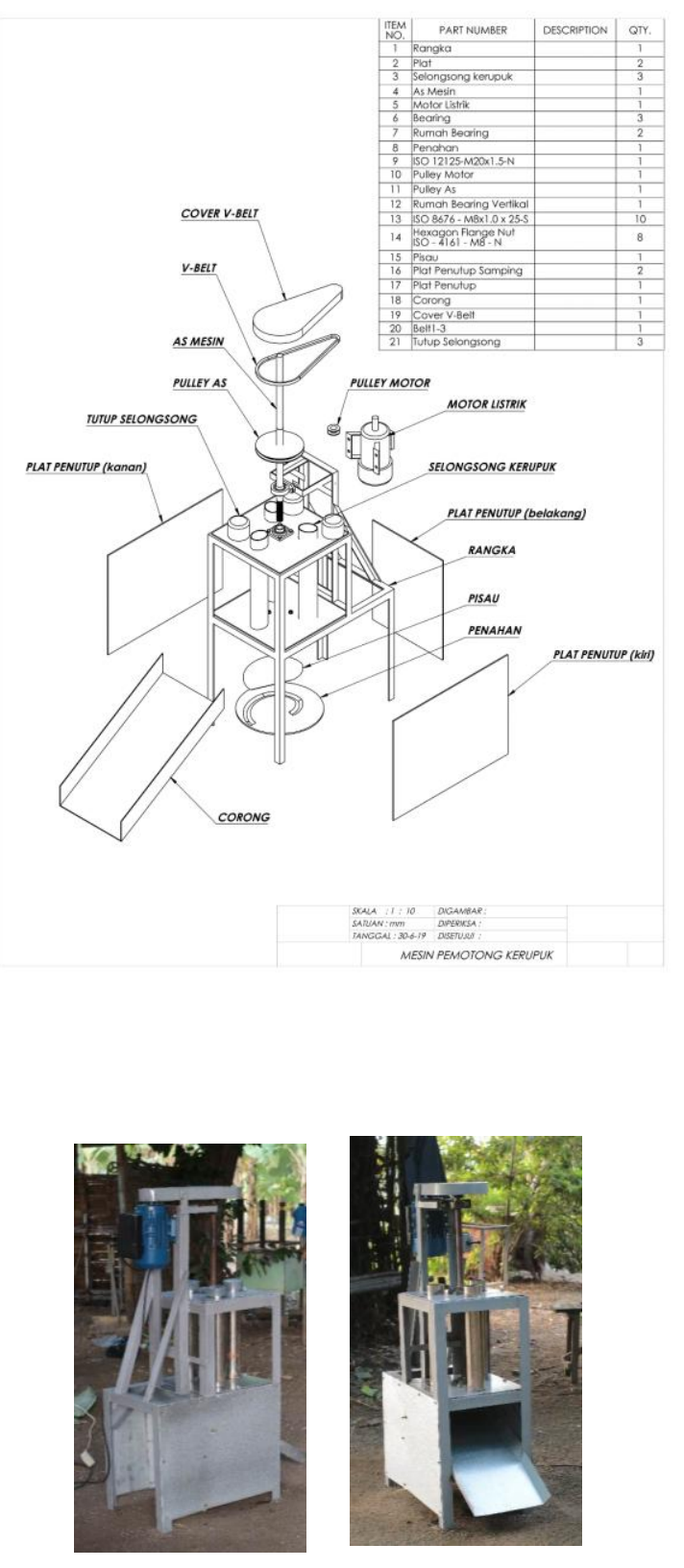

Gambar 2. Assembly Chart Alat pemotong kerupuk 
Merinci Strategi dengan Matriks Kontradiksi dan Menyusun Strategi yang sesuai dengan 40 TRIZ inventive rules

1. Cara agar alat dapat memotong lontongan kerupuk dengan kuat dan cepat

Tabel 2. Matriks Kontradiksi Parameter Strength (\#14)

\begin{tabular}{|c|c|c|c|c|c|c|c|c|}
\hline No & Keterangan & $\begin{array}{c}\text { Improving } \\
\text { parameters }\end{array}$ & $\begin{array}{c}\text { Worsening } \\
\text { parameters }\end{array}$ & $\begin{array}{l}\text { Inventive } \\
\text { principle }\end{array}$ & Penjelasan Prinsip & $\begin{array}{c}\text { Prinsip yang } \\
\text { Di pilih } \\
\end{array}$ & Penerapan & Rancangan Baru \\
\hline \multirow{4}{*}{1} & \multirow{4}{*}{$\begin{array}{c}\text { Cara agar } \\
\text { alat dapat } \\
\text { memotong } \\
\text { lontongan } \\
\text { kerupuk } \\
\text { dengan kuat } \\
\text { dan cepat }\end{array}$} & \multirow{4}{*}{$\begin{array}{l}\text { Strength } \\
\quad(\# 14)\end{array}$} & \multirow{4}{*}{$\begin{array}{l}\text { Loss of time } \\
\quad(\# 25)\end{array}$} & $\begin{array}{l}\text { Pneumatics } \\
\qquad \begin{array}{l}\text { and } \\
\text { hydraulics } \\
(* 29)\end{array}\end{array}$ & $\begin{array}{l}\text {-Gunakan gas dan cairan sebagai bagian } \\
\text { dari objek daripada menggunakan benda } \\
\text { padat. } \\
\text {-Gunakan gaya Archimedes untuk } \\
\text { mengurangi berat objek. }\end{array}$ & Tidak Dipilih & - & - \\
\hline & & & & $\begin{array}{c}\text { Local } \\
\text { quality }(* 3)\end{array}$ & $\begin{array}{l}\text {-Ubah struktur suatu objek dari seragam } \\
\text { menjadi tidak seragam. } \\
\text {-Buat setiap bagian dalam sebuah objek } \\
\text { sesuai dengan fungsinya. }\end{array}$ & Tidak Dipilih & - & - \\
\hline & & & & $\begin{array}{l}\text { Mechanical } \\
\text { Interaction } \\
\text { Substitution } \\
\quad(* 28)\end{array}$ & $\begin{array}{l}\text {-Gunakan part mekanik dengan sensor. } \\
\text {-Gunakan e lektrik, magnetik, dan } \\
\text { elektro magnetik untuk berinteraksi dengan } \\
\text { objek. } \\
\text {-Ubah dari statis menjadi dinamis (dapat } \\
\text { digerakkan). }\end{array}$ & Dipilih & $\begin{array}{l}\text { Menggunakan } \\
\text { motor } 3 / 4 \mathrm{HP} \\
\text { dan gearbox } \\
\text { untuk } \\
\text { menggerakkan } \\
\quad \text { launcher }\end{array}$ & \\
\hline & & & & $\begin{array}{l}\text { Preliminary } \\
\text { action }(* 10)\end{array}$ & $\begin{array}{l}\text { Melakukan perubahan sebelum } \\
\text { dibutuhkan, dengan melakukan perubahan } \\
\text { pada sistem atau objek. }\end{array}$ & Tidak Dipilih & - & - \\
\hline
\end{tabular}


2. Cara merancang alat agar mudah dioperasikan

Tabel 3. Matriks Kontradiksi Parameter Ease of Operation (\#33)

\begin{tabular}{|c|c|c|c|c|c|c|c|c|}
\hline No & Keterangan & $\begin{array}{l}\text { Improving } \\
\text { parameters }\end{array}$ & $\begin{array}{l}\text { Worsening } \\
\text { parameters }\end{array}$ & Inventive principle & Penjelasan Prinsip & $\begin{array}{l}\text { Prinsip } \\
\text { yang } \\
\text { Dipilih }\end{array}$ & Penerapan & Rancangan Baru \\
\hline \multirow{3}{*}{2} & \multirow{3}{*}{$\begin{array}{l}\text { Cara merancang } \\
\text { alat agar mudah } \\
\text { dioperasikan }\end{array}$} & \multirow{3}{*}{$\begin{array}{l}\text { Ease of } \\
\text { Operation } \\
\text { (\#33) }\end{array}$} & \multirow{3}{*}{$\begin{array}{c}\text { Stress or } \\
\text { pressure }(\# 11)\end{array}$} & Taking Out $(* 2)$ & $\begin{array}{l}\text { Memisahkan bagian yang } \\
\text { dapat mengganggu objek. }\end{array}$ & $\begin{array}{l}\text { Tidak } \\
\text { Dipilih }\end{array}$ & - & - \\
\hline & & & & $\begin{array}{l}\text { Optical property } \\
\text { changes }(* 32)\end{array}$ & $\begin{array}{l}\text { Ubah warna atau transparasi } \\
\text { dari sebuah objek atau ubah } \\
\text { warna atau transparasi dari } \\
\text { lingkungan luar objek. }\end{array}$ & $\begin{array}{l}\text { Tidak } \\
\text { Dipilih }\end{array}$ & - & - \\
\hline & & & & $\begin{array}{l}\text { Equipotentiality } \\
(* 12)\end{array}$ & $\begin{array}{l}\text { Ubah kondisi operasi untuk } \\
\text { mengeliminasi usaha dalam } \\
\text { me lawan medan } \\
\text { potensial.(mengurangi } \\
\text { kebutuhan atau menaikkan } \\
\text { atau menurunkan objek dalam } \\
\text { bidang gravitasi) }\end{array}$ & Dipilih & $\begin{array}{l}\text { Menambahkan } \\
\text { beban/ pemberat } \\
\text { kerupuk }\end{array}$ & \\
\hline
\end{tabular}


3. Cara merubah desain pisau agar stabil/ tidak goyang pada saat proses pemotongan

Tabel 4. Matriks Kontradiksi Parameter Shape (\#12)

\begin{tabular}{|c|c|c|c|c|c|c|c|c|}
\hline No & Keterangan & $\begin{array}{l}\text { Improving } \\
\text { parameters }\end{array}$ & $\begin{array}{l}\text { Worsening } \\
\text { parameters }\end{array}$ & $\begin{array}{l}\text { Inventive } \\
\text { principle }\end{array}$ & Penjelasan Prinsip & $\begin{array}{l}\text { Prinsip } \\
\text { yang } \\
\text { Dipilih }\end{array}$ & Penerapan & Rancangan Baru \\
\hline \multirow{4}{*}{3} & \multirow{4}{*}{$\begin{array}{c}\text { Cara merubah } \\
\text { desain pisau } \\
\text { agar stabil/ } \\
\text { tidak goyang } \\
\text { pada saat } \\
\text { proses } \\
\text { pemotongan }\end{array}$} & \multirow{4}{*}{ Shape (\#12) } & \multirow{4}{*}{$\begin{array}{l}\text { Strength } \\
(\# 14)\end{array}$} & $\begin{array}{l}\text { Flexible } \\
\text { shells and } \\
\text { thin films } \\
(* 30)\end{array}$ & $\begin{array}{l}\text {-Gunakan flexible shells dan lapisan film } \\
\text { tipis daripada struktur } 3 \text { dimensi. } \\
\text {-Isolasi objek atau sistem dari } \\
\text { lingkungan luar menggunakan flexible } \\
\text { shells dan film tipis. }\end{array}$ & $\begin{array}{l}\text { Tidak } \\
\text { Dipilih }\end{array}$ & - & - \\
\hline & & & & $\begin{array}{l}\text { Curvature } \\
\text { increase } \\
(* 14)\end{array}$ & $\begin{array}{l}\text {-Ubah bagian dari permukaan rata ke } \\
\text { lengkung, dari bentuk cekung ke bola. } \\
\text {-Gunakan roller, bola, spiral, dan kubah. } \\
\text {-Ubah gerakan linear ke berputar } \\
\text { menggunakan gaya sentrifugal. }\end{array}$ & Dipilih & $\begin{array}{l}\text { Mengubah desain } \\
\text { pisau menjadi } \\
\text { lebih lengkung }\end{array}$ & \\
\hline & & & & $\begin{array}{l}\text { Preliminary } \\
\text { action }(* 10)\end{array}$ & $\begin{array}{l}\text { Melakukan perubahan sebelum } \\
\text { dibutuhkan, dengan me lakukan } \\
\text { perubahan pada sistem atau objek. }\end{array}$ & $\begin{array}{l}\text { Tidak } \\
\text { Dipilih }\end{array}$ & - & - \\
\hline & & & & $\begin{array}{l}\text { Composite } \\
\text { materials } \\
(* 40)\end{array}$ & $\begin{array}{l}\text { Ubah dari material yang seragam } \\
\text { men jadi material composite. }\end{array}$ & Dipilih & $\begin{array}{l}\text { Menggunakan } \\
\text { material baja JIS } \\
\text { SKD } 11\end{array}$ & \\
\hline
\end{tabular}


V.2. Analisa Pengujian Alat Pemotong Kerupuk

Dari pengujian yang dilakukan, a lat dapat menghasilkan 3 potongan kerupuk dalam 1 rotasi. Pada saat proses pemotongan, pisau stabil dan tidak goyang namun masih belum optimal karena putaran yang dihasilkan oleh dinamo 3/4 HP terlalu tinggi dan tidak konstan yang menyebabkan torsi yang dihasilkan oleh dinamo rendah. Torsi yang rendah tersebut kurang kuat untuk memotong adonan kerupuk. Alat pemotong ini cukup mudah dioperasikan, operator hanya memasukkan adonan kerupuk di selongsong alat dan menunggu potongan kerupuk yang akan jatuh di corong alat. Desain alat tersebut juga dilengkapi dengan beban/ pemberat adonan kerupuk untuk membantu proses menekan adonan kerupuk namun beban tersebut belum dibuat karena proses pemotongan adonan yang belum optimal.

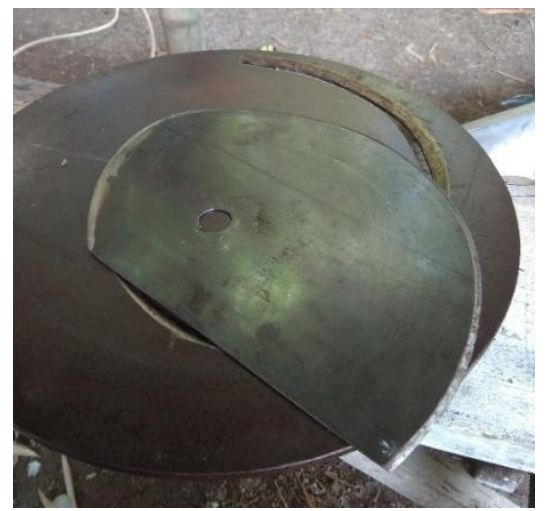

Gambar 3. Pisau Utama dan Penahan Pisau

\section{V.3. Urutan Proses Pengerjaan Alat Pemotong Kerupuk}

1. Menggambar desain plat Cover Launcher $40 \times 40 \mathrm{~cm}$ dan tebal $4 \mathrm{~mm}$ dengan menggunakan kertas duplek.

2. Membuat 2 buah plat $40 \times 40 \mathrm{~cm}$ dan tebal $4 \mathrm{~mm}$ dengan cara menjiplak desain dari kertas duplek lalu dipotong.

3. Membeli 2 buah pillowblock $(25 \mathrm{~mm}$ ASB persegi) dan 1 buah pillowblock (25 mm ASB laher UCP).

4. Membeli material rangka alat.

5. Membuat rangka alat pemotong kerupuk di bengkel las.

6. Membeli motor dinamo (FAMOZE PRO 0,75 HP).

7. Membeli material pisau atas (baja paduan JIS SKD 11 dengan tebal 1,5 $\mathrm{mm})$.

8. Menggambar desain pisau atas.

9. Membuat pisau atas dengan cara menjiplak desain dari kertas duplek pada material baja paduan JIS SKD 11 dengan tebal 1,5 $\mathrm{mm}$.

10. Menggambar desain penahan pisau dengan tebal $6 \mathrm{~mm}$ dan diameter 36,5 $\mathrm{cm}$.
11. Membuat penahan pisau dengan cara menjiplak desain dari kertas duplek dan dipotong.

12. Membeli AS dengan panjang $95 \mathrm{~cm}$ dan diameter $25,4 \mathrm{~mm}$.

13. Bubut AS di bengkel bubut.

14. Membeli 2 buah pulley (pulley AS dan pulley motor dinamo).

15. Membeli 3 buah pipa selongsong dengan tebal $1,5 \mathrm{~mm}$ dan panjang 50 $\mathrm{cm}$.

16. Membeli fanbelt ukuran A37, baut, mur, dan ring.

17. Merakit dan finishing seluruh bagian alat di bengkel.

\section{Kesimpulan dan Saran}

Kesimpulan dari perancangan pisau pemotong kerupuk dengan metode TRIZ yang telah dilakukan adalah pemotongan lebih produktif karena dapat memotong 3 lontongan dalam 1 kali rotasi, pisau lebih stabil atau tidak goyang dan pisau pemotong lebih aman karena pemasangan pisau dilakukan didalam dan tertutup. Selain itu penggunaan Baja JIS SKD 11 me mbuat pisau awet dan tahan lama.

Dalam mengembangkan peralatan in i perlu ditambahkan gearbox pada alat pemotong agar dapat menghasilkan torsi yang lebih besar, menggunakan fanbelt bergerigi untuk mendapatkan putaran yang pelan, kuat serta mengurangi terjadinya selip saat memutar as.

\section{Daftar Pustaka}

1. Aryontantra, Julian. 2018. "Perancangan Pisau Pemotong Kerupuk dengan Metode TRIZ".

2. Citro, Julius Kurniawan. 2018. "Perancangan Launcher Pemotong Kerupuk dengan Menggunakan Metode TRIZ".

3. Direktorat, Kredit dan UMKM, 2007, Pola Pembiayaan Usaha Kecil Syariah (PPUKSYA RIAH) “Usaha Kerupuk Ikan”. Jakarta: Gedung Tipikal (TP) Lt. V.

4. Muliawan, D., 1991, "Pengaruh Berbagai Tingkat Kadar Air Terhadap Pengembangan Kerupuk Sagu Goreng”, Skripsi Jur. TPG, Fak. Tekn.Pertanian, IPB, Bogor. Dalam Jurnal Teknologi dan Industri Pangan Vol XX No.1 Tahun 2009.

5. Sulamet-Ariobimo, R.D., "Pengaruh suhu tempering terhadap SKD 11 Mod.", Mesin Jurnal Ilmiah Teknik Mesin, 2006, Vol. 8, No. 3.

6. Koswara, Sutrisno., 2009, "Pengolahan aneka kerupuk", eBookpangan.com diambil 31 Januari, 2019.

7. Rantanen, Kalevi and Domb, Ellen, 2002, "Simplified TRIZ new problem-solving applications for engineering and manufacturing professional"s. United States of America: CRC Press LLC. 